\title{
Plantar Epidermoid Cyst in a Patient with Rheumatoid Arthritis
}

\author{
Hajime Yamanaka*, Hiroshi Tamai, Munetaka Suzuki, Tatsuya Kobayashi, and Yawara Eguchi \\ Department of Orthopaedic Surgery, National Hospital Organization Shimoshizu Hospital, Japan
}

Submission: January 10, 2018; Published: January 26, 2018

*Corresponding author: Hajime Yamanaka, Department of Orthopaedic Surgery, National Hospital Organization Shimoshizu Hospital, 934-5 Shikawatashi, Yotsukaido City, Chiba, 284-0003, Japan, Tel: +81-43-422-2511; Fax: +81-43-421-3007; Email: idi05343@r2.ucom.ne.jp

\begin{abstract}
Foot pain and deformity occur as presenting feature in many of patients with rheumatoid arthritis (RA) and some of them leading to painful callosities. Epidermoid cysts are common benign subcutaneous lesions. These occur from penetration of epidermal cells into underlying dermal tissue. It characterized as these are slow-growing, raised round-oval, firm intradermal cysts. It is commonly seen in hairy regions of body like scalp, face and trunk, can be single or multiple, but rarely can occur in glabrous skin of palm and sole. Epidermal cysts occur from penetration of epidermal cells into underlying dermal tissue. Here, we report a case of 71-year-old woman with RA patient, presented with complaints of swelling in her left fore-sole. A palpable firm lesion was located just below the 1st metatarsophalangeal (MTP) joint of left foot plantar. At first, it was considered as painful callosities, but examined on CT and MRI, not osseous lesion, subcutaneous soft tissue mass was detected. We excised it and sent for histopathological examination which confirmed it as planter epidermoid cyst.
\end{abstract}

Keywords: Epidermoid cyst; Plantar; Rheumatoid arthritis; Callositis

Abbreviations: RA: Rheumatoid Arthritis; MTP: Meta Tarso Phalangeal, MMP: Matrix Metallo Proteinase, STIR: Short-Inversion-Time Inversion Recovery

\section{Introduction}

Foot pain and deformity occur as the presenting feature in many patients with RA [1]. Deformities of the foot include dorsal dislocation of MTP joints, plantar callosities, flat-foot and hallux valgus deformity of the great toe, due to chronic synovitis [2]. Symptomatic planter callosities are the primary symptom affecting most RA patients. Epidermoid cysts are very common benign subcutaneous lesion and most commonly found in hairy regions on the scalp, face and neck and trunk [3]. They generally range in size from 0.2 to $5 \mathrm{~cm}$ and can be solitary or multiple masses, but rarely can occur in glabrous no hair follicle skin of palm and sole. They are known to result from progressive cystic ectasia of the infundibular portion of hair follicle, producing a lipid and keratin-filled cyst cavity [4]. It can be continuous growth until the cyst ruptures. But the pathogenesis in palmoplantar epidermoid cyst differs that is traumatic sequestration of epidermal elements into dermis [5].

A 71-year-old woman with RA has been complained of swelling in her left sole for one year. A palpable firm swelling was noted just below the left 1st MTP planter region. At first, it was diagnosed as a painful callosities, or corn caused by RA foot deformity. On X-ray foot no osseous lesion without hallux valgus or foreign body was detected, but can detected soft tissue tumor lesion in subcutaneous planter on computerized tomography (CT) and Magnetic resonance image (MRI). It was excised and the histopathological examination showed that it was epidermoid cyst.

\section{Case Report}

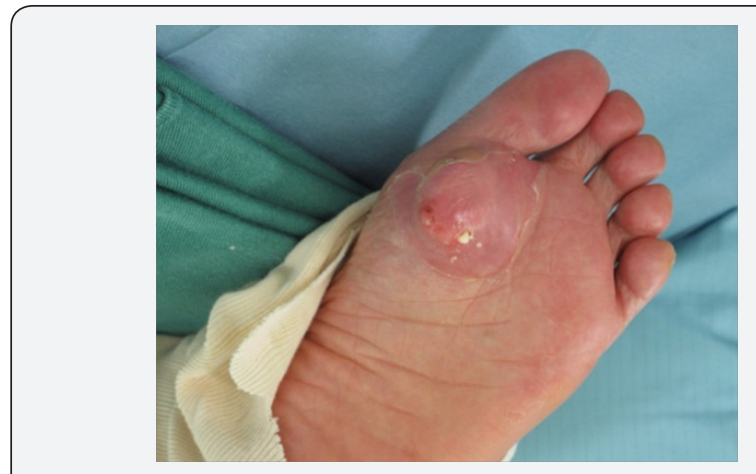

Figure 1: Photograph of the left foot taken preopreratively. A subcutaneous mass was elevated, firm, round, $2 \mathrm{~cm}$ in diameter overlying the $1^{\text {st }}$ metatarsal.

In January 2016, a 71-year-old woman with a 17-year history of RA presented to our hospital with complaints of pain at gait, discomfort during walking and swelling in her left sole. Patient history lasted for about 12 months gradually increasing in size. She had been medical therapy against RA at another hospital with predonisolone, $2 \mathrm{mg} /$ day, salazosulfapyridine, $1 \mathrm{~g} /$ day, and 
bucillamine, $150 \mathrm{mg}$ /day. According to the patient there was no history of trauma in her left sole. Local examination revealed a solitary $2 \times 2 \mathrm{~cm}$ round, firm soft tissue swelling located in the left foot under the head of 1st metatarsal (Figure 1). Swelling was in subcutaneous plane, not mobile. There was no sign of inflammation. The laboratory studies revealed a white blood cell count of $7500 / \mu \mathrm{L}$ (71.1\% neutrophils, 18.9\% lyphmcytes,), hemoglobin $13.2 \mathrm{~g} / \mathrm{dl}$, platelet count 197,000/dl, and C-reactive protein was $0.55 \mathrm{mg} / \mathrm{dl}$, Rheumatoid factor was $306.4 \mathrm{IU} / \mathrm{ml}$, and matrix metalloproteinase (MMP) $-3124 \mathrm{ng} / \mathrm{dl}$.

She had undergone treatment with a total contact insole on her left foot for several months at another hospital, recognized it as planter callosities, but the painful symptom did not improvement. At our hospital, we performed some radiological examinations. X-ray images of her left foot showed that hallux valgus of the great toe, hallux valgus angle (HVA) was $27^{\circ}$, but 2nd to 5th MTP joints did not recognize subluxation (Figure 2). Plain CT revealed the subcutaneous mass below the left 1st MTP joint that well capsulated mass with similar to water density (Figure 3).
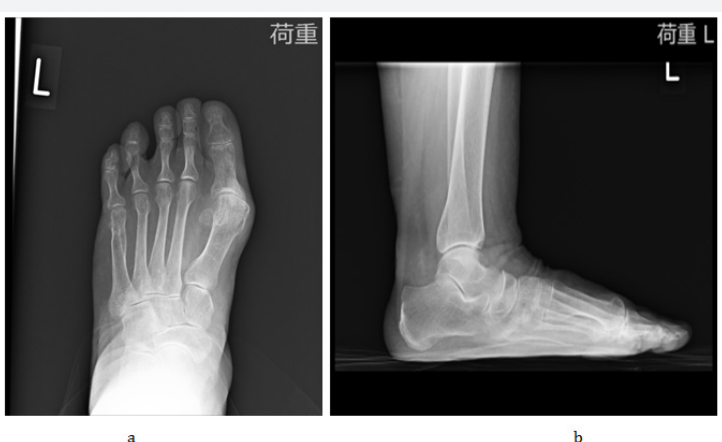

Figure 2: Radiographs of left foot.

a. Antero-posterior,

b. Latera view, showing hallux valgus on great toe, however no dislocation on $2^{\text {nd }}$ to $5^{\text {th }}$ MTP joints.

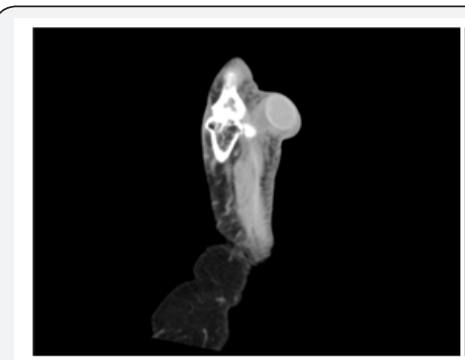

a

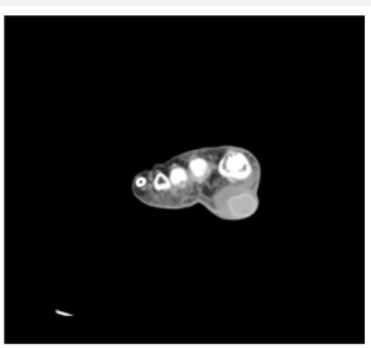

$\mathrm{b}$
Figure 3: Plain CT.

a. Sagittal,

b. Axial, images of left foot revealed a subcutaneous round mass on 1st MTP joint. Well capsuled mass in ovary mass was detected.

MRI showed the mass with low or intermediate signal density on T1 -weighted image, high signal density on T2 weighted image and high signal density on short-inversion- time inversion recovery (STIR) image (Figure 4). Foot ultrasonography and biopsy had not been performed. In March 2016, informed consent was obtained and excision of the swelling was performed under spinal anesthesia. Longitudinal skin incision was made over the swelling mass and the mass was excised and closed primary (Figure 5). Intraoperative finding was $2 \times 2.5 \mathrm{~cm}$ sized well encapsulated cystic lesion containing white pultaceous material (Figure 6). Excised tissue was sent for histopathological examination. The report showing a thin fibrocollagenous cyst, wall is lined by stratified squamous epithelium with prominent granular layer. Cyst contains lamellated keratin, which confirmed it as epidermoid cyst (Figure 7). The patient was followed clinically for 1 year after surgery without any recurrence of the symptom or the lesion.

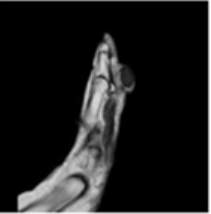

(a)

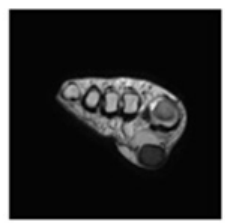

(b)

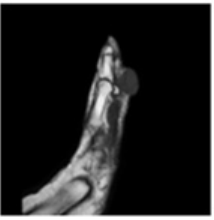

(c)

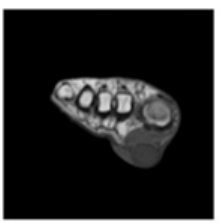

(d)

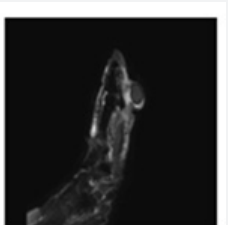

(e)

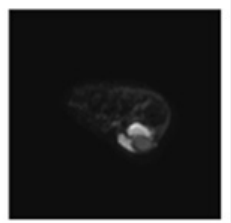

(f)
Figure 4: MRI images of the left foot with subcutaneous mass. Sagittal $(a, c, e)$, axial $(b, d, f)$ images. (a),(b) T1-weighted images revealed a well-define mass with low signal intensity in intermediate signal intensity mass. (c), (d) T2-weight images, and (e), (f) STiR images respectively.

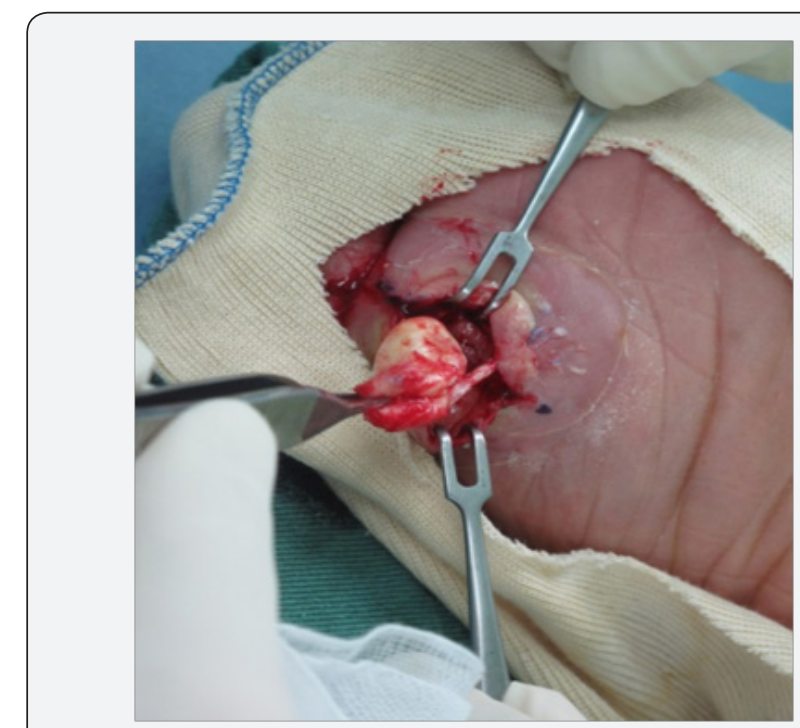

Figure 5: Intraoperative image showing an excised mass. 

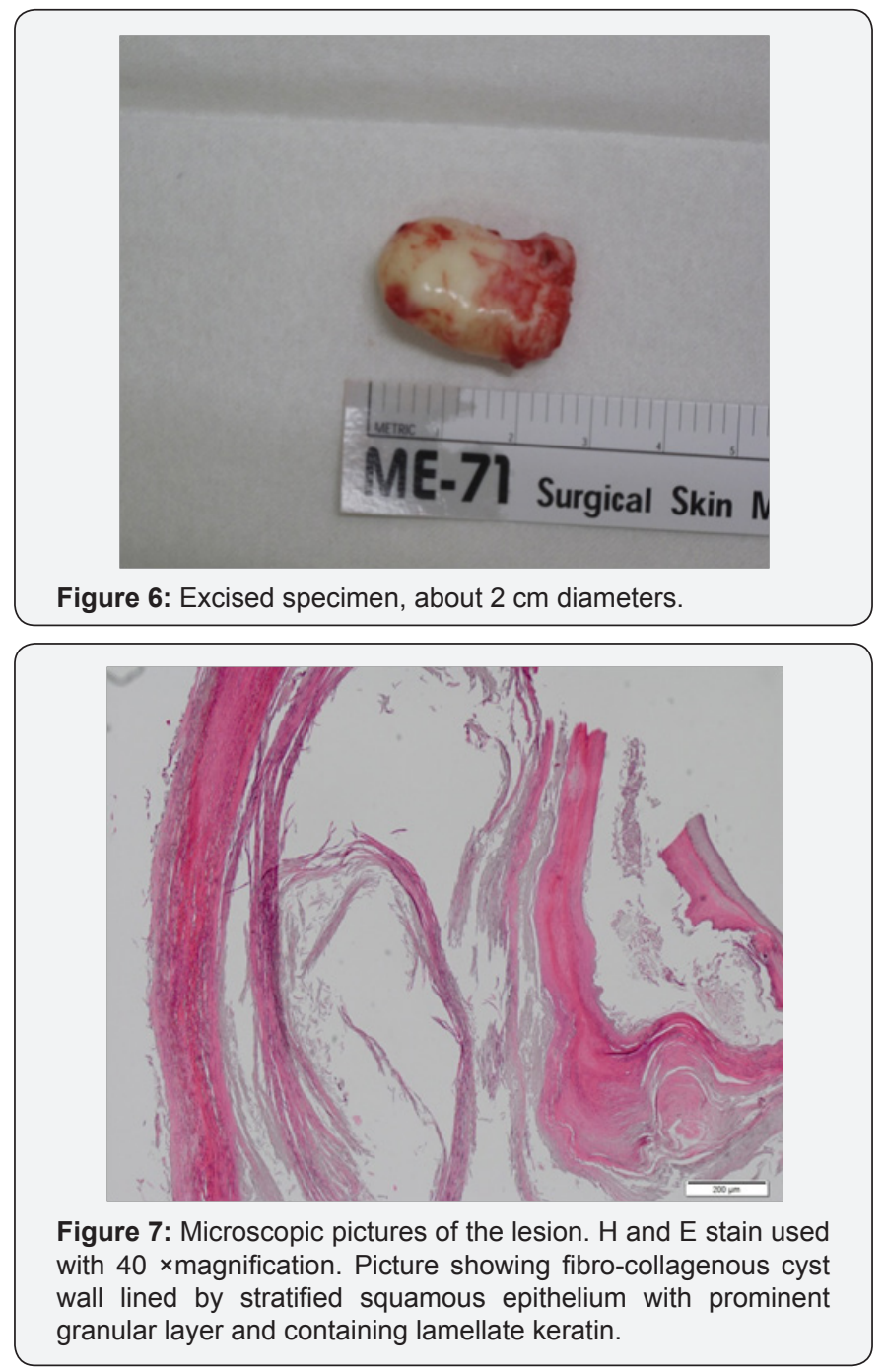

\section{Discussion}

Symptomatic planter callosities or corns are the primary symptom affecting most RA patients with forefoot deformity [1], but epidermoid cyst on plantar lesion with RA patient is rare. Epidermal cysts are the 5th most common pedal soft tissue lesion and account for $3.2 \%$ of all soft tissue masses of the foot [6]. Epidermoid cyst is a retention cyst in relation to sebaceous gland. It results from progressive cystic ectasia of the infundibular portion of hair follicle [7]. In palm and sole, as there are no sebaceous gland or hair follicle, so it was initially thought that epidermoid cyst does not occur in these regions, but as these cysts also presented in these regions hence different etiopathogeneses ware postulated that traumatic implantation of epidermal cells into the dermis or foreign body reaction [8] or plantar epidermal cyst may develop from eccrine duct due to Human Papilloma Virus (HPV) infection [9].

To make a diagnosis, CT, MRI and ultrasonography are useful [10]. CT and MRI are more specific for soft tissue masses and will typically reveal a semi-solid mass with several interspersed fluid-filled cavities [11]. But a benign epidermal cyst cannot be differentiated from a malignant masse on CT, MRI or ultrasonography. In some case, needle aspiration biopsy was done to confirm the diagnosis [12]. Planter epidermal cysts need to differentiate from calluses, warts, and other diseases [13]. The treatment consists of surgical excision of the whole lesion, including capsule of the cyst, to avoid recurrences. Complications in the form of inflammation, infection and rupture with foul smelling discharge may occur in epidermoid cyst. Most importantly, the cells must be confirmed because of the possibility of malignant transformation. Although epidermoid cysts are benign lesion, malignant transformation into basal cell carcinoma and squamous cell carcinoma has been described in few cases [14].

In RA patients, forefoot pain is a common clinical problem. Many disorders produce discomfort in the metatarsal region of the forefoot. These disorders include traumatic lesions of the soft tissues and bones (turf toe, plantar pale disruption, sesamoiditis, stress fracture), Freiberg infraction, tendon disorder (tendinosis, tenosynovitis, tendon rupture), nonneoplastic soft-tissue masses (ganglion, bursitis, granuloma, Morton neuroma plantar fibromatosis) and soft-tissue and bone benign neoplasms (hemangioma, giant cell tumor, lipoma, schwannoma, osteochondroma), malignant tumor (chondrosarcoma osteosarcoma, Ewing sarcoma squamous cell carcinoma) [14-16]. It should be differentiated from these disorders when RA patient complaints of forefoot pain.

\section{Conclusion}

In conclusion, we described RA patient with forefoot pain and mass. The diagnosis was rare plantar epidermoid cyst. It should be differenciated from other disorders, such as planter callosities.

\section{Conflict of Interest}

None.

\section{References}

1. Naniwa T, Iwagaitsu S, Tamechika S, Maeda S, Niimi A (2016) Signs of forefoot joint synovitis have a limited impact on patient's perception of rheumatoid arthritis disease activity and acute-phase reactants. Mod Rheumatol 26(2): 200-205.

2. Shimizu Y, Sakita K, Arai E, Tsuchida T, Ogawa, F, et al. (2005) Clinicopathologiac features of epidermoid cysts of the sole: comparison with traditional epidermal cysts and trichilemmal cysts. J Cutan Pathol 32(4): 280-285.

3. Hall JP, Sheffey RJ, Chaqares WE, Yong RM (2006) Epidermal inclusion cyst in the foot of a Vietnam veteran. J Am Podiatr Med Assoc 96(5): 445-447.

4. Choi JE, Kwon IH, Seo SH, Kye YC, Ahn HH (2016) Pathogenesis of Planter epidermal cyst: three-dementional reconstruction analysis. Ann Dermatol 28(1): 133-135. 
5. Egawa K, Egawa N, Honda Y (2005) Human Papillomavirus-associated plantar epidermoid cyst related to epidermoid metaplasia of the eccrine duct epithelium: a combined histological, immunohistochemical, DNA-DNA in situ hybridization and three-dimentional reconstruction analysis. Br J Dermatol 152(5): 961-967.

6. Ashman CJ, Klecker RJ, Yu JS (2001) Forefoot pain involving the metatalsal region: differential diagnosis wth MR imaging. Radiographics 21(6): 1425-1440.

7. Coulter PD, Bouché RT (1999) Traumatically induced inclusion cyst secondary to shoe impigiment; report of three cases. J Foot Ankle Surg 38(8): 410-413.

8. Murari TM, Callaghan JJ, Berrey BH, Sweet DE (1989) Primary benign and malignant osseous neoplasms of the foot. Foot Ankle Int 10(2): 68-80.

9. Ma LD, McCarthy EF, Bluemke DA, Frassica FJ (1998) Differentiation of benign from malignant muskloskeletal lesions using MR imaging: pitfalls of in MR evaluation of lesions with a cystic appearance. Am J Roentgenol 170(5): 1251-1258.

10. Mafee MF, Kumar A, Heffner DK (1994) Epidermoid cyst (cholesteatoma) and cholesterol granuloma of the temporal bone and epidermoid cysts affecting the brain. Neuroimaging Clin N Am 4(3): 561-578.

11. Shibata T, Hatori M, Satoh T, Ehara S, Kokubun S (2003) magnetic resonance imaging features of epidermoid cyst in the extremities. Arch Orthop Trauma Surg 125(5): 239-241.

12. Misner SC, mariash SA, Alvarez G (1991) Ruptured plantar epidermoid inclusion cyst with foreign body giant cell reaction. J foot Surg 30(1): $38-42$.

13. Fisher BK, Macpherson M (1986) Epidermoid cyst of the sole. J Am Acad Dermatol 15(5): 1127-1129.

14. Sheff J, Bregman P, Currant T (1988) bilaterally symmmetrical epidermal inclusion cysts with foreifn-body giant-cell reaction. JAPMA 88(8): 410-413.

15. Staals EL, Bacchini P, Mercuri M, Bertoni F (2007) Dedifferentiated chondrosarcomas arising in preexisting osteochondromas. J Bone Joint Surg Am 89(5): 987-993.

16. Llombart B, Serra-Guillén C, Monteagudo C, López Guerrero JA, Sanmartín O (2013) Dermatofibrosarcoma protuberans: a comprehensive review and update on diagnosis and management. Semin Diagn Pathol 30(1): 13-28.

\section{Your next submission with Juniper Publishers will reach you the below assets}

- Quality Editorial service

- Swift Peer Review

- Reprints availability

- E-prints Service

- Manuscript Podcast for convenient understanding

- Global attainment for your research

- Manuscript accessibility in different formats

( Pdf, E-pub, Full Text, Audio)

- Unceasing customer service

Track the below URL for one-step submission

https://juniperpublishers.com/online-submission.php 